\title{
A model of larval dispersion coupling wind-driven currents and vertical larval behaviour: application to the recruitment of the annelid Owenia fusiformis in Banyuls Bay, France
}

\author{
C. Verdier-Bonnet ${ }^{1}$, F. Carlotti ${ }^{1, *}$, C. Rey $^{1,2}{ }^{1}$ M. Bhaud ${ }^{2}$ \\ ${ }^{1}$ Université P. et M. Curie, Observatoire Océanographique, BP 28, F-06230 Villefranche-sur-mer, France \\ ${ }^{2}$ Université P. et M. Curie, Observatoire Océanographique, Laboratoire Arago, BP 44, \\ F-66651 Banyuls-sur-mer Cedex, France
}

\begin{abstract}
We present a mathematical model of larval dispersal into a coastal zone dominated by wind-driven currents: larvae are considered as active particles tracked by the 3-D (3-dimensional) velocities calculated by a physical model sophisticated enough to give a good representation of the 3-D structure of wind-driven currents. As an application, we model the larval recruitment of the annelid Owenia fusiformis in Banyuls Bay, France, located at the southwest extremity of the Gulf of Lions. The currents are generated by the permanent offshore Liguro-Provençal circulation and by time-varying winds, the swimming behaviour of larvae is assumed to be only vertical, the spawning zones are in 2 adjacent bays and the pelagic phase lasts about $\$ \mathrm{wk}$. Larvae are assumed to be successfully recruited if they settle after pelagic morphological changes on the substratum suitable to their benthic development. Larvae which do not belong to the successful recruitment either settle too young on the suitable substratum or go out of the suitable substratum. The model shows that the fate of the larvae tracked by the currents appears to be determined early in the pelagic phase by being trapped in low current zones. Simulations allow the deduction of the advection losses for different winds: the proportion of larvae reaching the adult habitat is $60 \%$ at maximum for downwelling conditions and $15 \%$ at minimum for initial upwelling conditions. Our results indicate too that under the most frequent wind conditions no mixing occurs between populatıons of the 2 adult habitat zones which are $1.6 \mathrm{~km}$ apart from each other and that no successful recruitment occurs from larvae coming from bays located at the north of the considered coastal zone. Only combinations of changing wind conditions could permit arrival of larvae from Paulilles Bay to Banyuls Bay. The interest of such individual-based models consists not only in increasing our understanding of the link between spatial and temporal dynamics of meroplanktonic populations but also in allowing us to explore the potential effects of habitat alteration on those populations.
\end{abstract}

KEY WORDS: Numerical modelling - Larval dispersion Wind-driven currents . Annelid Owenia fusiformis

\section{INTRODUCTION}

Many benthic organisms have a complex life cycle in which the early stages are pelagic larval forms. During this planktonic phase, larvae are dispersed from their release site by currents. For species with a long pelagic

- Addressee for correspondence.

E-mail:carlotti@ccrv.obs-vlfr.fr larval phase (in the order of a week to a month), mesoscale spatial physical structures have a significant influence on the dispersal or retention of larvae (De Wolf 1974, McConaugha 1992, Tremblay et al. 1994). Knowledge of the physical and biological processes involved in the larval dispersion are important for understanding the survival or the extinction of marine populations, and gene flows between spatially distinct populations, especially when the adult phase is sessile (Planes 1993). The difficulties in observing and collect- 
a

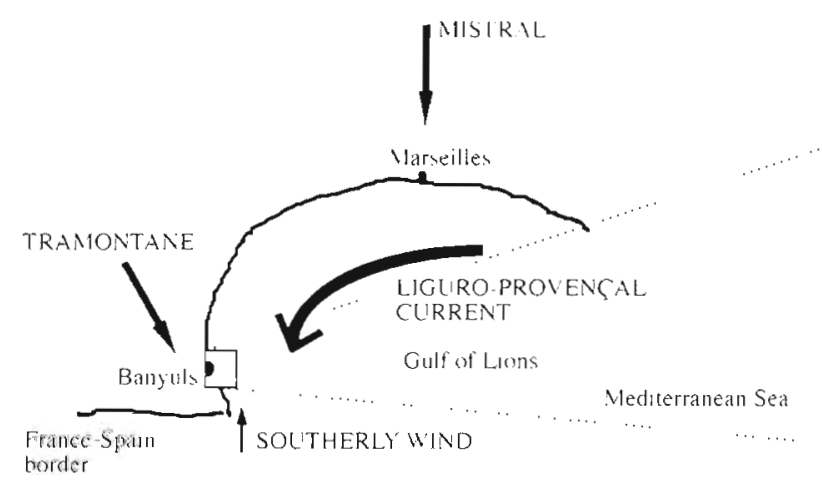

b

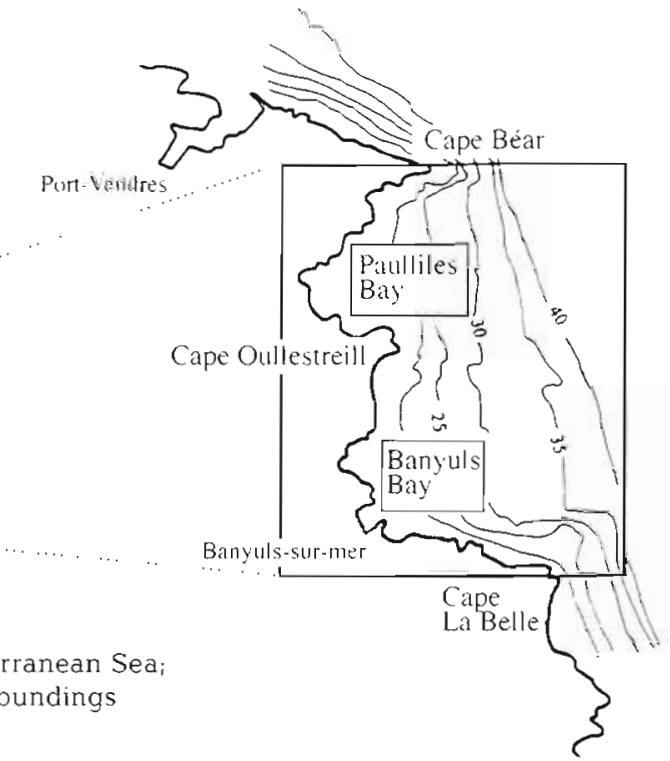

Fig. 1. (a) Location of the studied area in the western Mediterranean Sea; (b) bathymetry (in meters) of the studied area and its surroundings

ing such small organisms in the field justify the very few experiments and measurements made on larval dispersal (Richards et al. 1995). Even though recent reviews (Butman 1987, Snelgrove \& Butman 1994) do not mention the use of coupled 3-D (3-dimensional) physical and biological models as tools of future research, mathematical models solving the interaction between physical structures and larval behaviour are useful to understand the processes involved (Hill 1990, 1991, Richards et al. 1995, Carlotti 1996). These models consider differently their biological and physical representations: 1 of the 2 components, the physical one or the biological one, is often reduced (see for instance Eckman 1994). Few studies (Black \& Moran 1991, Black et al. 1991) have addressed the actual dispersal of larvae in coastal areas of a few kilometres long in relation to small-scale hydrodynamics, owing largely to insufficient detail at an appropriate time scale (Scheltema 1986).

An intensive study has been conducted within the framework of the French 'Programme National sur le Déterminisme du Recrutement' (PNDR) since 1986, in order to understand the dynamics of 2 populations of annelids, Pectinaria koreni and Owenia fusiformis, first in the Bay of Seine and now in Banyuls Bay (France). The first site is characterised by an estuarine circulation. The study of this site can then be reduced in the simplest way to a 2-D (2-dimensional) problem along an idealised longitudinal section of the Seine Estuary. The results of a sophisticated 2-D biological model with advection terms forced by a depth-dependent velocity (Carlotti 1996) have been successfully compared with field studies (Lagadeuc 1990, Lambert 1991. Thiébaut 1994). For the second site, the study cannot be space-simplified because of the physical processes involved such as winds. Banyuls Bay is indeed located at the southwest extremity of the Gulf of Lions in the cyclonic Liguro-Provençal general drift and is frequently exposed to nor thwesterly or southerly winds (Fig. 1a) from February to the beginning of May when the larvae of Owenia fusiformis are found in Banyuls Bay. The physical problem is thus 3-D. The role of wind in the dispersal of meroplanktonic larvae is especially difficult to estimate, but is crucial (Bertness et al. 1996).

The aim of this paper is to contribute, using a modelling approach, to the estimation of the role of the permanent physical structure induced by the offshore Liguro-Provençal circulation, and the role of variable physical forcing such as winds, on the persistence of the Owenia fusiformis population in Banyuls Bay. We use a sophisticated physical model zone (Verdier-Bonnet et al. 1997) in Banyuls Bay, in order to achieve a good representation of wind-driven currents in the studied coastal zone. In the presented work, the swimming behaviour of larvae is assumed to be only vertical (Rey 1995). Larvae are considered as particles tracked by the 3-D velocities calculated by the physical model.

\section{THE MODEL}

Location of the study and meteorological data. The study was undertaken in 2 adjacent bays at Banyuls and Paulilles (Fig. 1b), in the northwest Mediterranean Sea (Fig. 1a). In order to attain a good representation of the flow in these bays, we considered the extended zone $(3.4 \mathrm{~km}$ on the east-west and $4.6 \mathrm{~km}$ on the southnorth axis) delimited to the west by the coast, to the east by the offshore boundary at $1 \mathrm{~km}$ from Cape Béar, and to the north and south by 2 east-west boundaries, the first extending eastwards from Cape Bear and the second extending eastwards from Cape La Belle. For southward currents, Paulilles Bay and Banyuls Bay lie 
in the shadow of Cape Béar and Cape Oullestreill, respectively. Since Cape Béar juts further into the sea, Paulilles Bay is better protected from southward currents than Banyuls Bay. In contrast to Cape Béar, which represents a sharp discontinuity in the coastline, Cape La Belle protudes only slightly from the coast. Offshore of Capes Béar and La Belle, the sea bottom falls away abruptly, whereas the bottom between the 2 Capes slopes down gently and the depths in Paulilles and Banyuls Bays are shallower than $20 \mathrm{~m}$ (Fig. 1b).

The main physical characteristics of this site are the presence of the offshore Liguro-Provençal general drift from north to south and the dominant northwesterly wind called the tramontane (Fig. 1a). Southerly winds do occur, however they are less frequent (Table 1); measurements of the wind given by Météo France (1 record every 3 h) at Cape Béar during March and April for 1990 to 1993 show that the tramontane (i.e. winds which have a direction between $315^{\circ}$ and $360^{\circ}$ ) blew $61 \%$ of the time with an average direction of $340^{\circ}$ and the southerly wind (direction varying between $160^{\circ}$ and $225^{\circ}$ ) was observed for $22 \%$ of the time with an average direction of $190^{\circ}$. As an example, for March 1992, the southwesterly wind blew for the first $1.25 \mathrm{~d}$ with an average intensity of $12 \mathrm{~m} \mathrm{~s}^{-1}$, the tramontane was then dominant for the following $27 \mathrm{~d}$, with an average intensity of $13 \mathrm{~m} \mathrm{~s}^{-1}$ (Fig. 2).

Biophysical coupling. A biological model and a physical model are coupled in the following way: first the physical model is run with a particular physical scenario (winds, boundary conditions, etc.), then the biological model is used. Larvae, considered as particles, are tracked in the 3 -D velocity field calculated by the physical model, using a standard Euler integration.

$$
\mathrm{X}^{n+1}=\mathrm{X}^{n}+\Delta t\left(\mathrm{U}_{\mathrm{L}}+\mathrm{U}_{o w}\right)^{n}
$$

$\mathbf{U}_{\mathrm{L}}$ is the Lagrangian velocity of the fluid at position $\mathbf{X}$ and $n$ is the time increment. It is linearly interpolated from the points where the Eulerian velocity $\mathbf{U}_{E}$ of the fluid is calculated by the physical code. The time step $\Delta t$ is automatically chosen so that the maximum distance moved during each step was less than $1 / 10$ of a mesh interval. The tracking algorithm allows the options of passive or active particles with the additional velocity components $U_{o w}$ specified to represent biological behaviour.
Enough velocity fields are recorded to accurately take account of the variations of the wind: when the wind is blowing, the stationary state is reached after about $10 \mathrm{~h}$ and we have 1 record every $0.5 \mathrm{~h}$, so we can assume a constant velocity during $1 / 20$ of the transient characteristic time, i.e. between 2 successive records.

Physical model for the calculation of the Eulerian velocity field $\mathrm{U}_{\mathrm{E}}$. Assumptions and equations: The OCKE3D code [code Océanique et Côtier à deux équations supplémentaires de type $k-\varepsilon$ (KE) tridimensionnel (3-D); Verdier-Bonnet 1996) is used to predict the circulation in Banyuls Bay. The fluid is considered as incompressible. Since the sea is homogeneous during the considered period, buoyancy effects are not taken into account here; however they can be considered and introduced through the density variations due to salinity and temperature effects by assuming the Boussinesq approximation. In order to study local processes, the hydrostatic condition is not retained. The molecular diffusion is considered negligible in comparison to the turbulent one. Under the above conditions and with the $f$-plane assumption, the coastal circulation is modelled by the Reynolds averaged Navier-Stokes equations (see Verdier-Bonnet et al. 1997 for details).

The turbulence closure model, introducing 2 additional $k-\varepsilon$ equations, connects the turbulent fluxes with the mean fields, using the eddy kinematics viscosity $v_{e}$, which is expressed as a function of the turbulent kinetic energy $k$ and of its dissipation rate $\varepsilon$. The eddy movement is then assumed to be isotropic.

Boundary conditions: At the initial time, the fluid is at rest and a weak initial turbulence level is imposed since a zero turbulence condition is numerically unacceptable. The free-surface elevation is determined by a transport equation. On the free surface, the vertical stress of the horizontal velocity components is expressed as a function of the wind speed at $10 \mathrm{~m}$ above the free surface. At the northern limit of the bay, the Liguro-Provençal current is given. Its value was measured during calm weather (Rouault 1971) and is corrected when the wind is blowing (Verdier-Bonnet 1996). At the bottom and at the free surface, the turbulence quantities are given under the following assumption: the velocity follows a logarithmic friction law and turbulence equilibrium (production = dissipation) is reached.

Table 1. Characteristics of the wind at Cape Béar between March and April, 1990 to 1993

\begin{tabular}{|c|c|c|c|c|c|c|c|c|}
\hline \multirow{2}{*}{ Wind } & \multicolumn{2}{|c|}{ Direction } & \multirow{2}{*}{$\begin{array}{c}\text { Duration } \\
\text { (proportion) }\end{array}$} & \multicolumn{5}{|c|}{ Intensity $\left(\mathrm{m} \mathrm{s}^{-1}\right)$} \\
\hline & Range & Average & & $<5$ & $5-10$ & $10-15$ & $15-20$ & $>20$ \\
\hline Northwesterly & $315^{\circ}-360^{\circ}$ & $340^{\circ}$ & $61 \%$ & $19 \%$ & $22 \%$ & $18 \%$ & $14 \%$ & $27 \%$ \\
\hline Southerly & $160^{\circ}-225^{\circ}$ & $190^{\circ}$ & $22 \%$ & $28 \%$ & $33 \%$ & $30 \%$ & $8 \%$ & $1 \%$ \\
\hline
\end{tabular}




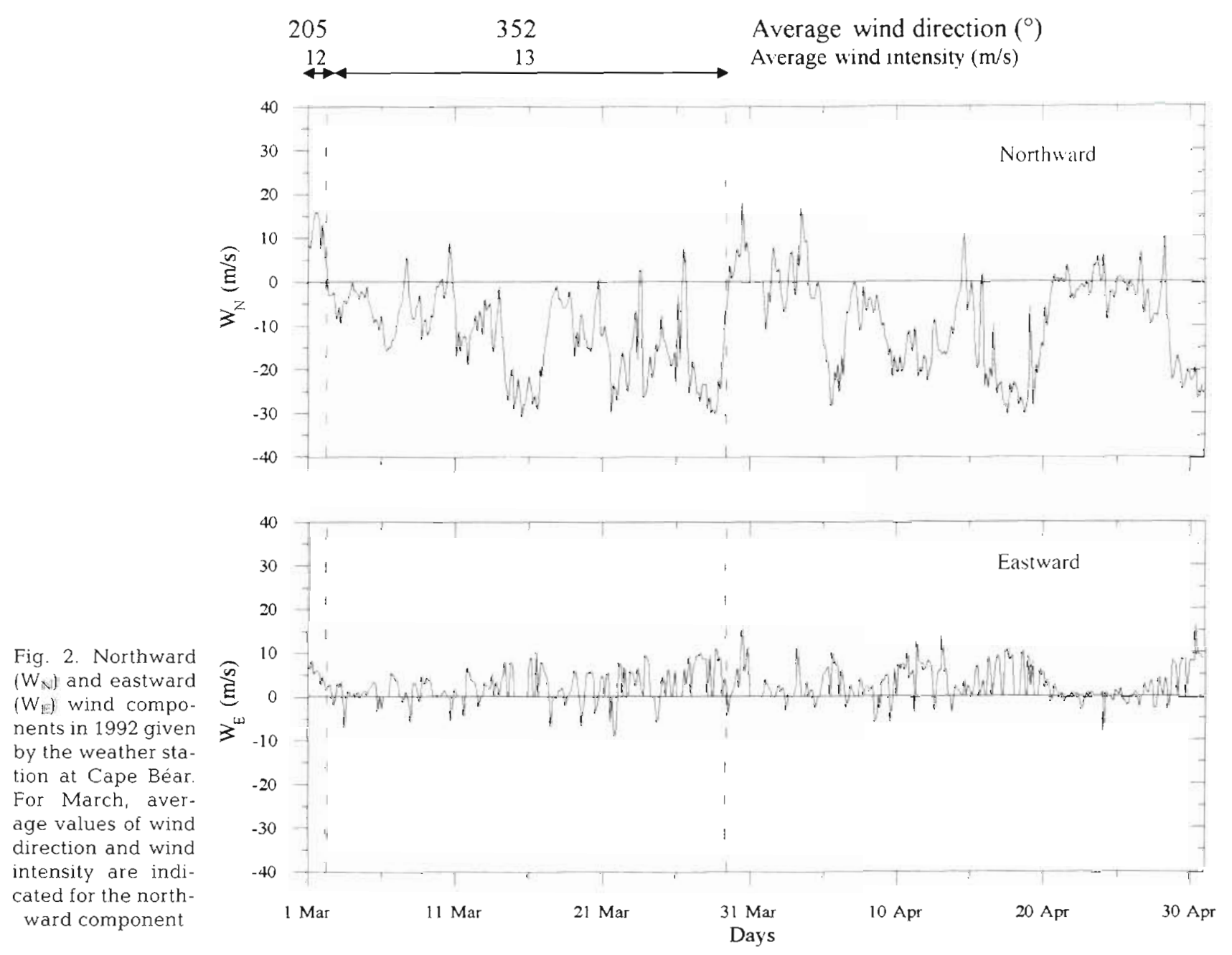

Numerical resolution: The discrete equations are obtained through finite volumes with a 3-D Cartesian staggered mesh of MAC type. The system is solved by an explicit resolution algorithm which, by an iterative procedure at each time step, couples the correction of the dynamic pressure by using the artificial compressibility method and the correction of the hydrostatic pressure due to the free-surface elevation obtained by the resolution of a transport equation. The discrete equations are space-centred for all the terms except for the advection ones which require the classical upwind scheme (Peyret \& Taylor 1983), and the first order explicit time scheme of Euler is used.

For the representation of the circulation in Banyuls Bay, the horizontal and vertical grid spacing is taken as equal to $200 \mathrm{~m}$ and $4 \mathrm{~m}$ respectively. The coast (Fig. 3a) and the sea bed are approximated by a series of steps.

The biological model. Life cycle and swimming behaviour of Owenia fusiformis: We refer the reader to 2 reviews on $O$. fusiformis by Snelgrove \& Butman (1994) and Arnoux et al. (1995). The larvae are considered as particles with 2 characteristics: their age and the vertical swimming speed $W_{o w}$. The pelagic cycle of O. fusiformis lasts 4 wk at most (Wilson 1932) (Fig. 4). First, the spawned eggs rise to the surface because they are less dense than the water. The $1 \mathrm{~d}$ old ones metamorphose into young mitraria larvae (stages 1 to 3 of Wilson 1932). These young larvae float near the surface for about $15 \mathrm{~d}$ (Thiébaut 1994). Morphological changes occur when the larvae are about $17 \mathrm{~d}$ old: the trunk of the future juvenile appears (Bhaud et al. 1987), larvae then become negatively buoyant and they sink towards the bottom. They are then considered as old larvae: stages 4 and 5 of Wilson (1932). When they reach the substrate, they metamorphose into worms (Rey 1995). This access to the substrate is fundamentally passive (Rey 1995, Nozais 1996) and larvae do not have the capacity to return to the water column. The nature of the substrate does not seem to control the success of metamorphosis. Only later will the substrate be revealed as suitable or not for the benthic development of juveniles.

The upward velocity of the Owenia fusiformis eggs is estimated at $2.5 \mathrm{~mm} \mathrm{~s}^{-1}$ (Thiébaut 1994). Measure- 
a

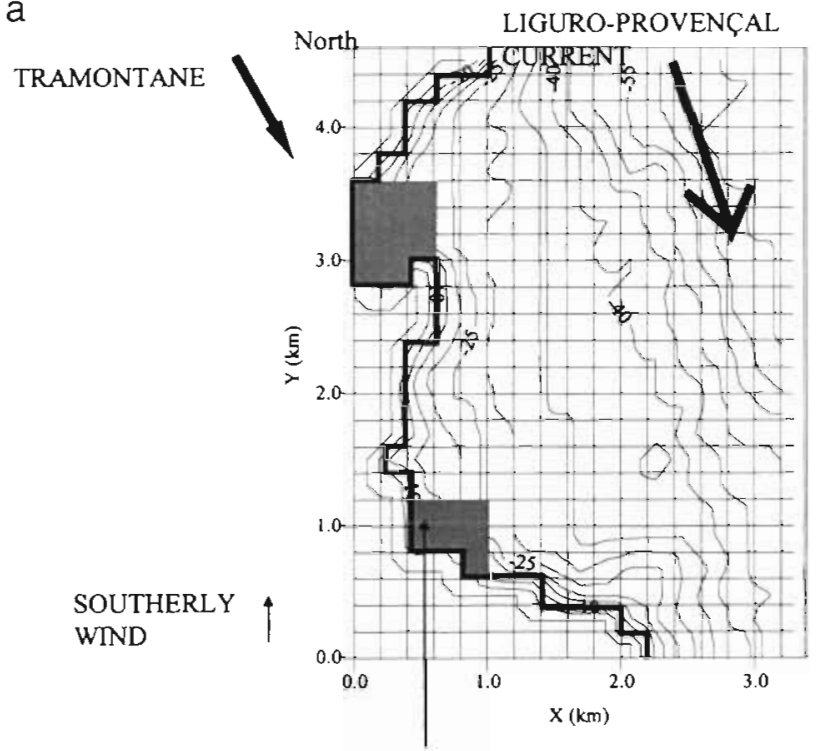

b

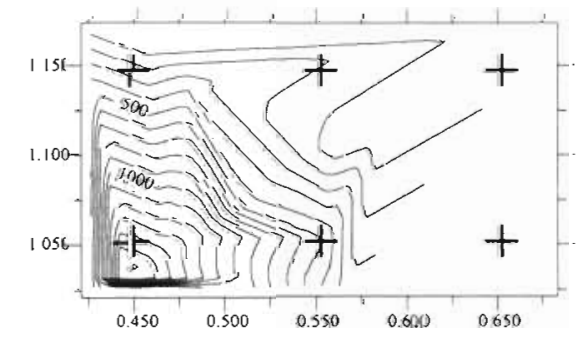

Fig. 3. (a) Schema of the studied area. Shaded areas indicate the presence of adult populations of Owenia fusiformis; bathymetry (in meters) is given. (b) Density (ind. $\mathrm{m}^{-2}$ ) of adults on the bottom of the Bay of Banyuls in a $250 \mathrm{mlong}$ and $150 \mathrm{~m}$ wide area (the mesh size is horizontally $200 \times 200 \mathrm{~m}$ )

(Rey 1995); + : larval emission points of the model ments made for different polychaete species give velocities of vertical migration between 0.5 and $5.2 \mathrm{~mm} \mathrm{~s}^{-1}$ (Chia et al. 1984). The young mitraria larvae can be considered as passive individuals (Thiébaut 1994). The sinking velocity of the old larvae has been measured using an actographic recording (the actographic apparatus allowed tracking of a single larva by means of a computer-driven moveable video camera mounted on rails; Duchêne \& Nozais 1994); lateral oscillations are not significant (Rey 1995). The average value found is $0.76 \mathrm{~mm} \mathrm{~s}^{-1}$ with a confidence interval from 0.24 to $1.28 \mathrm{~mm} \mathrm{~s}^{-1}$. This is quite low compared to other polychaete species like for example the $1.9 \mathrm{~mm} \mathrm{~s}^{-1}$ sinking velocity of Errantia and Sedentaria Polychaeta (Mileikovsky 1973), and high compared to the theoretical value of $0.0113 \mathrm{~mm} \mathrm{~s}^{-1}$ calculated by Thiébaut (1994) for O. fusiformis in the Seine Estuary as needed to obtain vertical larval migration consistent with in situ observations.

In the model, a mathematical law which gives the velocity of an Owenia fusiformis individual depending on its age (Fig. 4) has been elaborated from the characteristic values determined by experimental measurements (Thiébaut 1994, Rey 1995): during the first day after spawning, the individual as an egg is rising to the surface with a velocity of $2.5 \mathrm{~mm} \mathrm{~s}^{-1}$; after hatching and for the following $15 \mathrm{~d}$, the velocity of the larva is zero; as the larva becomes older, the larval velocity is given by a time-dependent hyperbolic tangent law (Fig. 4). This law describes the continuous time course of the larval velocity, consistent with the increase of the larval density: the phenomenon cannot be discontinuous because it is not the result of larval metamorphosis.

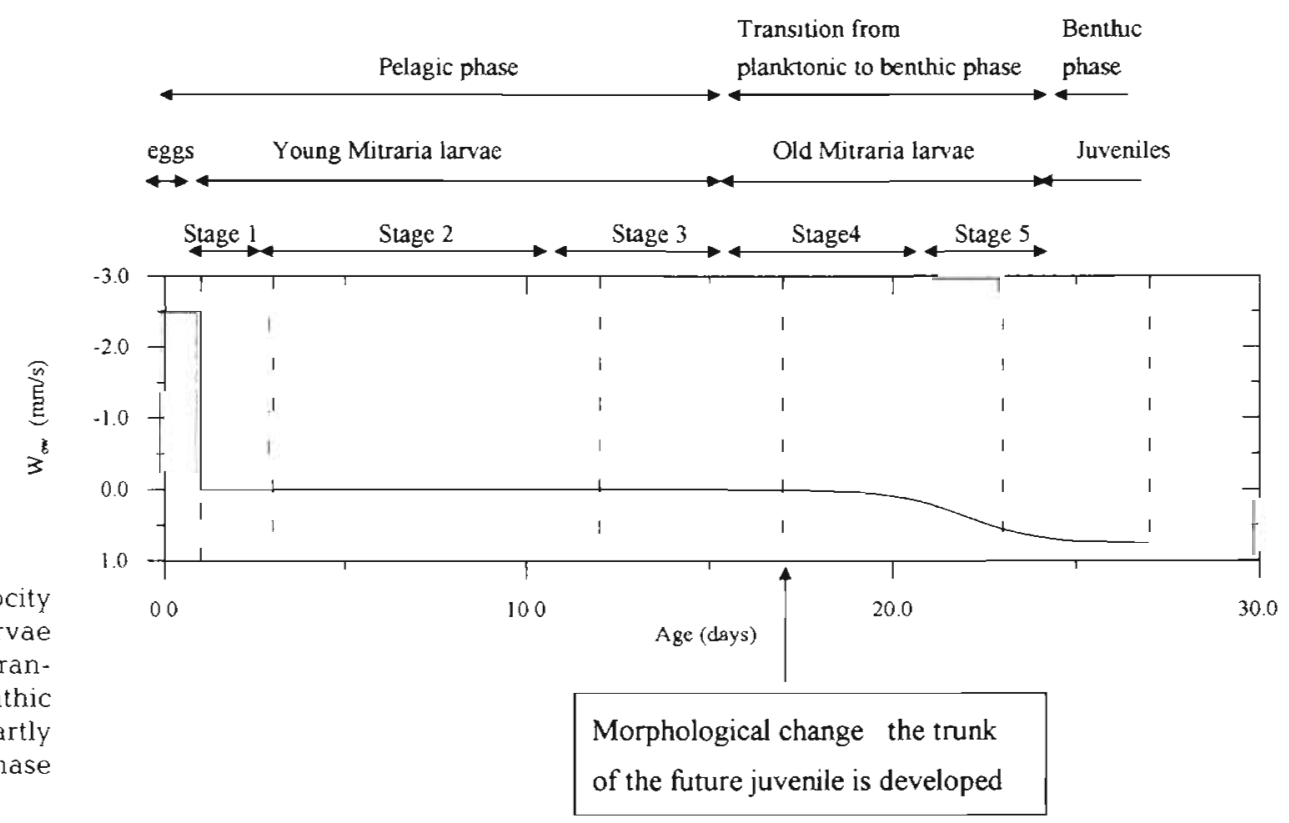

Fig. 4. Vertical swimming velocity $\left(W_{\text {ow }}\right)$ of Owenia fusiformis larvae depending on their age. (The transition from planktonic to benthic phase is completely or partly pelagic. Thus the pelagic phase lasts 16 to $28 \mathrm{~d}$ ) of the future juvenile is developed 
Initial position of the particles: The area of the adult habitat has been determined in several studies (Guille 1971, Rey 1995) carried out with benthic grab samples taken at different stations in each bay. The latter study showed higher density in Banyuls Bay (Fig. 3b). The density of adults appeared to be higher in Banyuls Bay (up to 1690 ind. $\mathrm{m}^{-2}$ ) than in Paulilles Bay (up to 24 ind. $\mathrm{m}^{-2}$ ). However the overall size of the habitat might be greater in Paulilles Bay $\left(0.44 \mathrm{~km}^{2}\right.$ vs $0.28 \mathrm{~km}^{2}$ in Banyuls Bay). In the model, we do not take into account the density of produced eggs, but just follow the history of individuals produced at different points of the adult habitat.

Simulations. During the pelagic phase of Owenia fusiformis ( $27 \mathrm{~d}$ ), 4 main wind conditions were retained:

- Two situations with a constant wind for the $27 \mathrm{~d}$ :

(1) The reference state without any wind, which is not consistent with in situ observations;

(2) The dominant situation: tramontane with an average direction of $340^{\circ}$ and a consistent average intensity $\left(10 \mathrm{~m} \mathrm{~s}^{-1}\right.$ ) (see Fig. 2)

- Two simplified cases with time variations of the wind which could be consistent with average in situ observations (see Fig. 2):

(3) No wind for the first day after spawning and tramontane $\left(340^{\circ}, 10 \mathrm{~m} \mathrm{~s}^{-1}\right)$ thereafter;

(4) Southerly wind $\left(190^{\circ}, 10 \mathrm{~m} \mathrm{~s}^{-1}\right)$ for the first $3 \mathrm{~d}$ after spawning, no wind for the following $12 \mathrm{~h}$ and tramontane $\left(340^{\circ}, 10 \mathrm{~m} \mathrm{~s}^{-1}\right)$ thereafter. The $190^{\circ}$ direction of the southerly wind is the average one (Table 1) and its $10 \mathrm{~m} \mathrm{~s}^{-1}$ intensity is consistent with the observed average (see Fig. 2).

For the location and the age of larvae at the initial time, 2 situations with regularly spaced individuals (every $100 \mathrm{~m}$ ) were retained. In the first case, eggs are spawned in the bay: 44 initial positions of larvae from Paulilles Bay and 28 initial positions of larvae from Banyuls Bay (Fig. 3). To simplify the discussion in the text, larvae are numbered from west to east and from north to south from 1 to 72 . In the second case, larvae originated from eggs spawned in bays further to the north, 28 h old larvae were assumed to enter the bay through the northern boundary of the studied area (see Fig. 3).

\section{RESULTS}

\section{Circulation in the bay}

As preliminary results, we present the circulation in Banyuls Bay for the most common wind situations: the tramontane $\left(340^{\circ}, 10 \mathrm{~m} \mathrm{~s}^{-1}\right.$ ) (case 2) first and then the southerly wind $\left(190^{\circ}, 10 \mathrm{~m} \mathrm{~s}^{-1}\right)$ (beginning of case 4). For both situations, the stationary state is reached for a

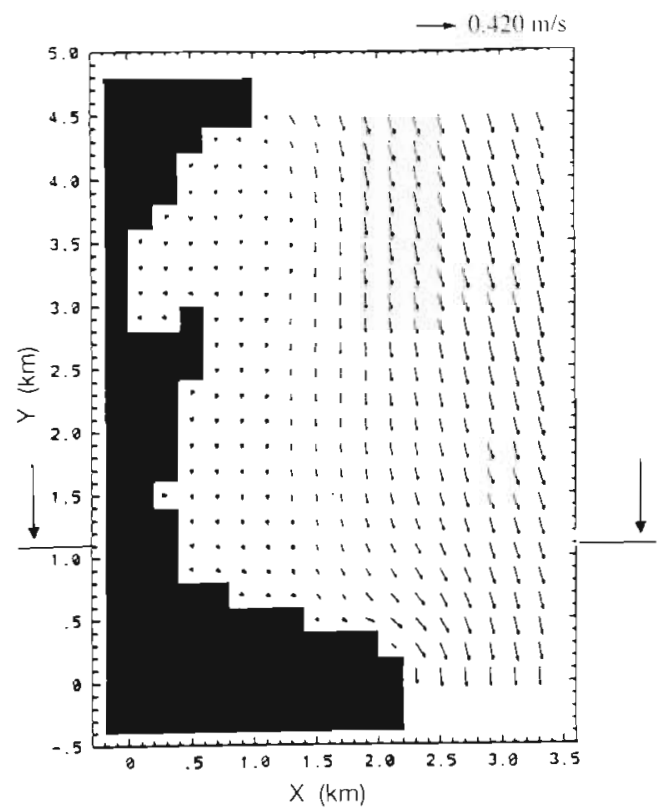

b

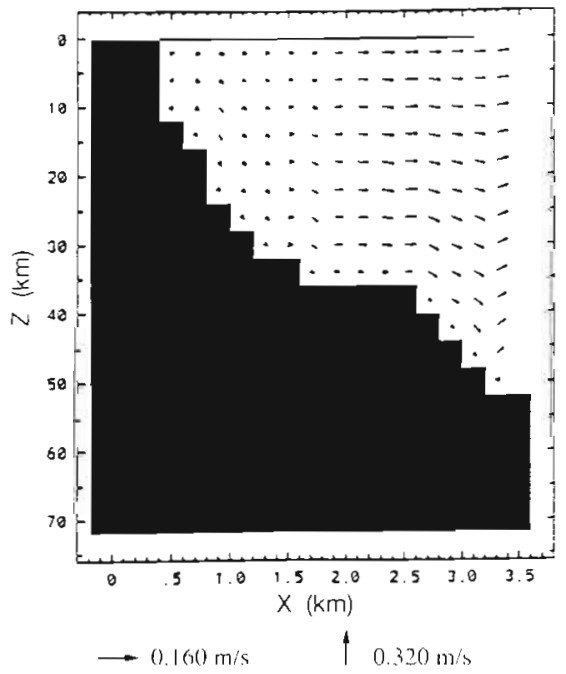

Fig. 5. Currents generated by the offshore Liguro-Provençal circulation and by a constant tramontane $\left(340^{\circ}, 10 \mathrm{~m} \mathrm{~s}^{-1}\right)$ (case 2). (a) Horizontal circulation at $2 \mathrm{~m}$ under the initial free-surface level; large arrows indicate the sectional elevation shown in (b). (b) Downwelling circulation at $y=1.1 \mathrm{~km}$

about $10 \mathrm{~h}$ (7000 cycles of calculation). When the tramontane is blowing, the global surface circulation in the considered zone is oriented from north to south (Fig. 5a). Near the coast, downward currents are generated (Fig 5b). When the southerly wind is blowing, the global offshore surface circulation is oriented from the northwest to the southeast (Fig. 6a). This surface offshore current immediately generates a free-surface depression near the coast. Upward currents (Fig. 6b) then appear due to the local mass balance in the vertical (Verdier-Bonnet et al. 1997). On an $800 \mathrm{~m}$ wide band, along the coast, the surface flow is oriented 


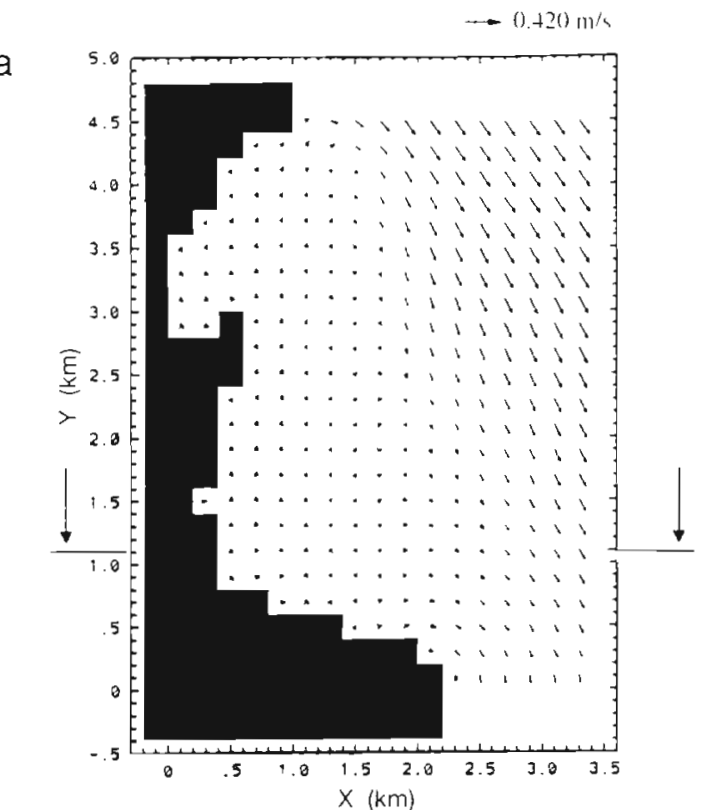

b

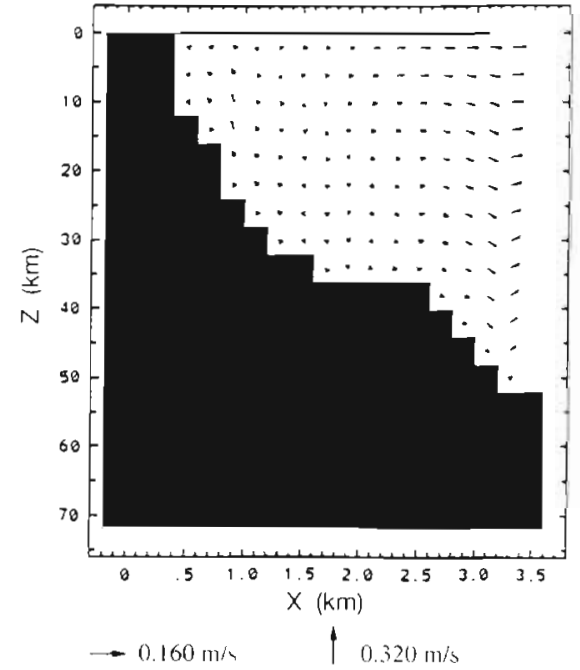

Fig. 6. Currents generated by the offshore Liguro-Provençal circulation and by a constant southerly wind $\left(190^{\circ}, 10 \mathrm{~m} \mathrm{~s}^{-1}\right)$ (beginning of case 4). (a) Horizontal circulation at $2 \mathrm{~m}$ under the initial free-surface level; large arrows indicate the sectional elevation shown in (b). (b) Upwelling circulation at $y=1.1 \mathrm{~km}$

northwards (Fig. 6a), i.e. in the opposite direction to the offshore Liguro-Provençal forcing. Through the southern open boundary, the outflow is weak compared to that observed with the tramontane (Fig. 5a): $5360 \mathrm{~m}^{3} \mathrm{~s}^{-1}$ versus $9040 \mathrm{~m}^{3} \mathrm{~s}^{-1}$. In both cases, near the coast, the vertical component of the velocity can reach $0.0001 \mathrm{~m} \mathrm{~s}^{-1}$ and the horizontal component intensity is lower than $0.10 \mathrm{~m} \mathrm{~s}^{-1}$ (Fig. 7). Thus, the wind conditions significantly modify the circulation: the tramontane generates downwelling currents while the southerly wind creates an upwelling circulation. In both cases, the bathymetry has an influence on the currents: the flows follow the bottom variations (Figs. 3, 5b \& 6b) Offshore, the iso-intensity lines of the horizontal components of the surface flow velocity follow the isobaths (Figs. $3 \& 7$ ). This phenomenon may be explained by the following process: in shallow waters, the bottom shear slows down the flow throughout the water column.

a

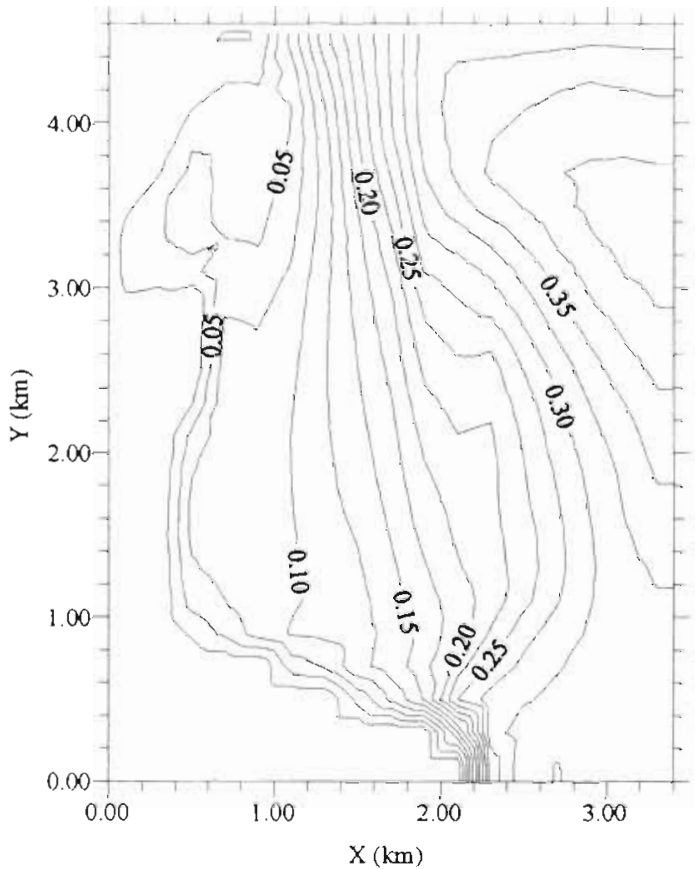

b

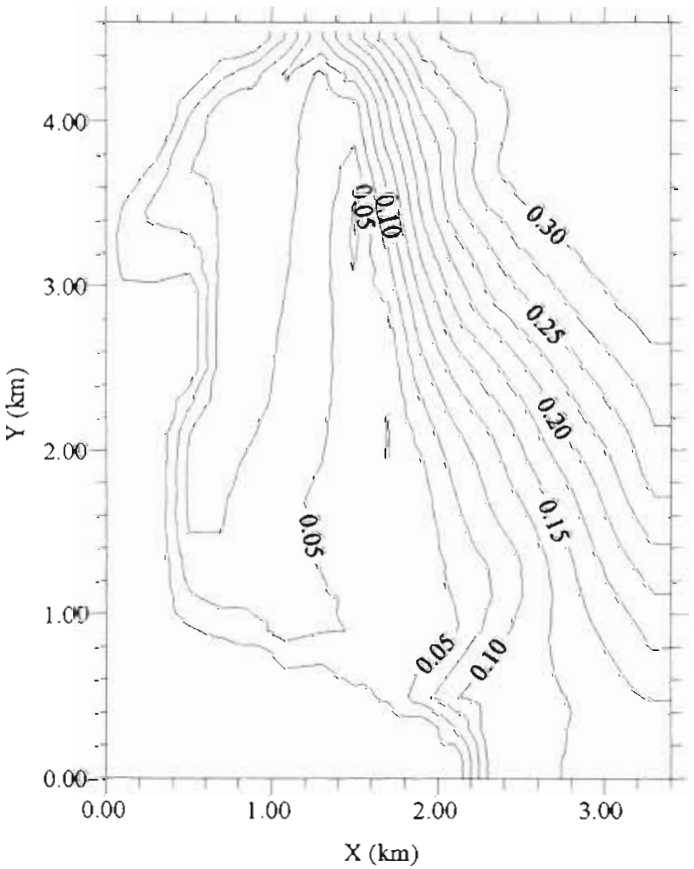

Fig. 7. Iso-intensity lines of the horizontal components of the flow velocity at $2 \mathrm{~m}$ under the initial free-surface level for the 2 situations. (a) Case 2; (b) beginning of case 4 


\section{Results for recruitment}

Larvae are assumed to be successfully recruited if they settle on a substratum suitable for their benthic development, at stage 4 or 5 , because the morphological changes have then been completed: the trunk of the future juvenile is developed. The ethological and ecological changes occur when the larvae reach the

a

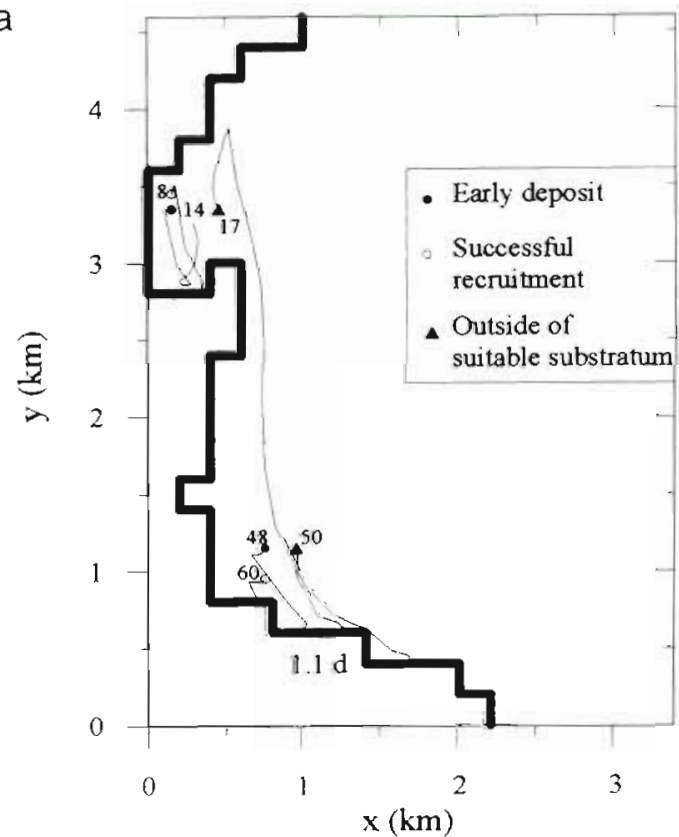

b

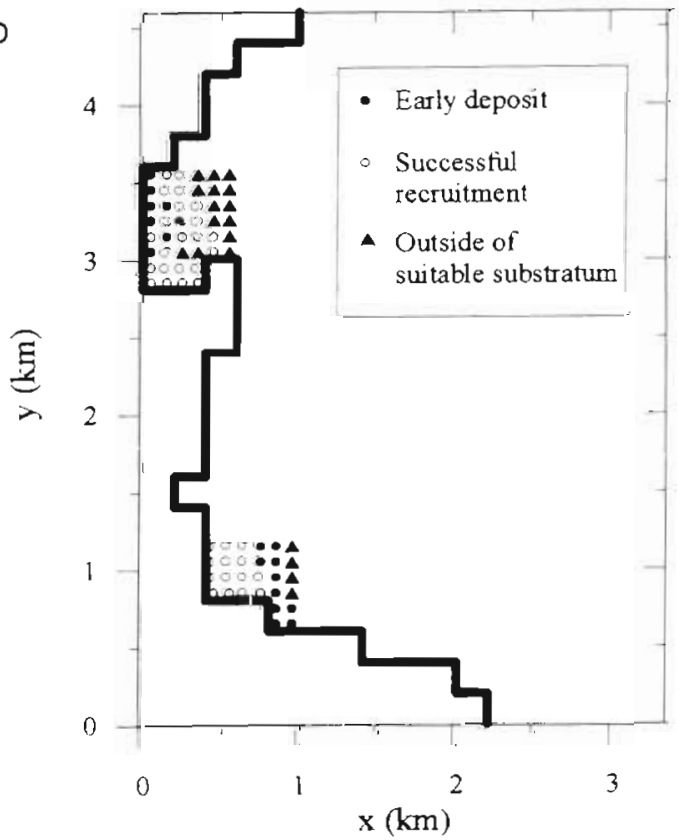

Fig. 8. For case 3: (a) tracks of drifting larvae; each larva is numbered; (b) a schematic representation of the future of larvae spawned in the bays substratum: they become worms. If they settle before reaching the fourth stage, they are considered as dead because they are assumed to be too delicate to complete their development on the substratum. Autorecruitment concerns the recruitment derived from larvae spawned in Banyuls and Paulilles Bays. For the hydrodynamic conditions of case 3 , larval tracks and the influence of the starting position of larvae are studied. Other wind conditions are then analysed. In the last part, the recruitment of larvae from other bays is modelled.

Tracks of larvae in the bays with tramontane $1 \mathrm{~d}$ after spawning (case 3)

The tracks drawn in Fig. 8a represent 3 situations: some larvae settle too young onto the suitable substratum $(\bullet)$, some belong to the successful recruitment (o) and others leave the suitable zone (4). Larva no. 14 (Fig. 8a), which spawns in Paulilles Bay, reaches the surface $1.3 \mathrm{~h}$ later, and is then transported by the horizontal currents at the surface for $23 \mathrm{~h}$. In the middle of Paulilles Bay, downward vertical currents carry it onto a suitable substratum at $1.6 \mathrm{~d}$ old (Fig. 9) which is too young to be included in successful recruitment. Larva no. 8 , which spawns near larva no. 14 (100 m away), is counted in the successful recruitment: after $29 \mathrm{~h}$, it has reached a zone without currents (Fig. 8a) near Cape Oullestreill. Then the larva begins sinking (Fig. 9) due to its own increase of density represented by the hyperbolic tangent law (see Fig. 4). Larva no. 8 reaches a suitable substratum at $12 \mathrm{~m}$ depth at $20 \mathrm{~d}$ old (Fig. 9).

Larva no. 17, which spawns in Paulilles Bay, is first transported northwards and then carried southwards (Fig. 8a). After 1.8 d, it has reached a zone of unsuitable substratum in Banyuls Bay, although near a suitable one. Like larva 8 , its own density carries it down to the bottom and it reaches the bottom at $20.5 \mathrm{~d}$ old. Since, however, it has now reached a substratum not suitable for its benthic development, it is not counted into the successful recruitment.

The processes described for the larvae spawned in Paulilles Bay can be extended to those originating in Banyuls Bay (see the tracks of larvae nos. 48,50 and 60 in Fig. 8a).

\section{Starting positions of larvae and recruitment}

Fig. 8 b gives a schematic representation of the future of larvae as a function of their starting positions, for the wind conditions of case 3 . In Banyuls Bay, the successfully recruited larvae are located at the western end of the bay. Larvae originating from the eastern adjacent 
Fig. 9. For case 3, time course of the vertical position of 3 larvae numbered as in Fig. 8a. The initial and final depths are indicated in brackets

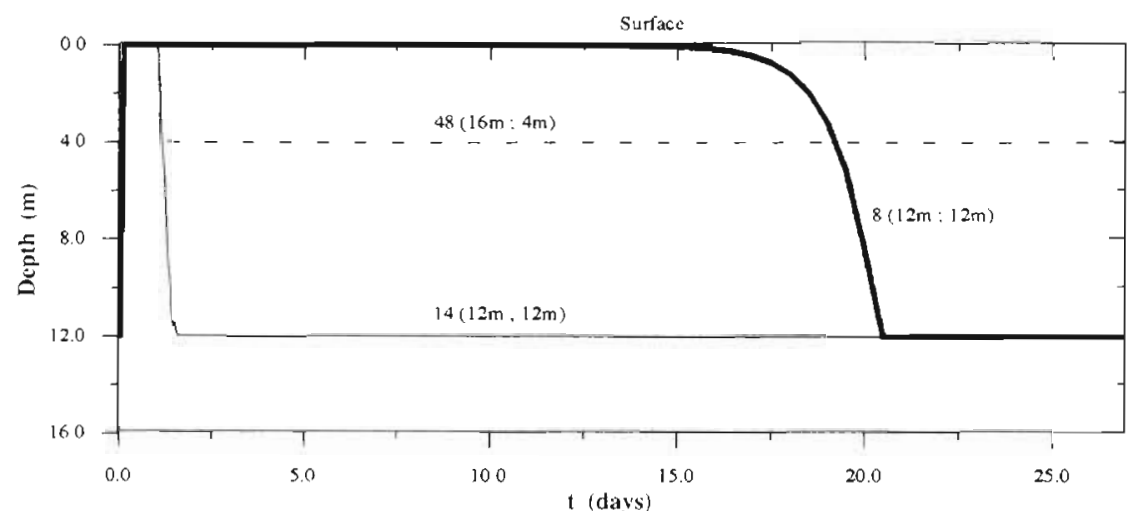

band of 100 to $200 \mathrm{~m}$ width reach the bottom too young at a shallow depth $(4 \mathrm{~m})$ near the point $x=0.9 \mathrm{~km}$ and $y=1.5 \mathrm{~km}$ (see the horizontal and vertical tracks of larva no. 48 in Figs, 8 a \& 9). Larvae spawned to the east of this zone are considered to be lost for recruitment too: either they settle on a substratum outside the zones suitable for their benthic development, i.e. outside Banyuls and Paulilles Bays, or they leave the studied domain through the eastern and southern open boundaries. In Paulilles Bay, even though the distribution is more complex, 3 global characteristics can be distinguished: larvae lost for successful recruitment are located either too far east where they settle onto a substratum not suitable for their benthic development, or too far west, close to the coast, where they settle on a suitable substratum too young to perform their metamorphosis into benthic worms. Finally, $50 \%$ of simulated larvae originating in Banyuls Bay and $50 \%$ originating in Paulilles Bay are successfully recruited under case 3 .

For all the chosen wind conditions (cases 1 to 4 ), the 2 characteristics of the influence of the starting larval positions on the recruitment are (Fig. 10a): successfully recruited larvae are issued from the western part of the spawning zones, near the coast: larvae which settle on the bottom outside the suitable zones are spawned in the east of the 2 bays. For cases 2 and 4 , the distribution of the larval starting positions as a function of the larval future is regular: there are at the most 3 zones (for larvae which have an early deposit, a successful recruitment and which settle outside the suitable substratum) that are distinct. For cases 1 and 3, the distribution is complex: 3 zones can be isolated globally but there are some exceptions especially in Paulilles Bay. For example, for case 3, 1 recruited larva is surrounded by larvae which will have an early deposit on the suitable substratum. With the wind conditions of cases 1 to 4 , the highest part of recruitment originates from Paulilles (Fig. 10b). For example, for case 4 , there is no successful recruitment from Banyuls Bay (Fig. 10b): all the eggs spawned in this zone go out through the eastern open boundary and are lost for recruitment.

\section{Kinetics of recruitment following wind conditions}

The model also permits a represention of the recruitment of larvae to the benthos as could be observed in silu. The number of larvae which reach substratum suitable for their benthic development is analysed in

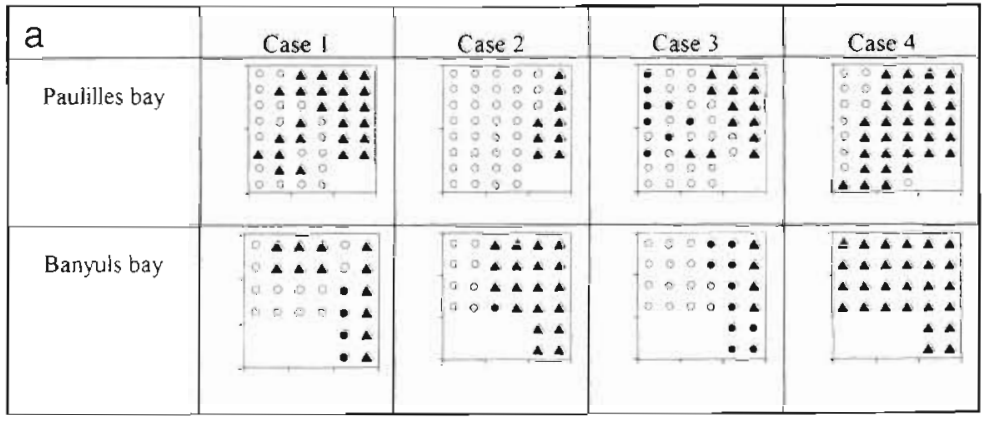

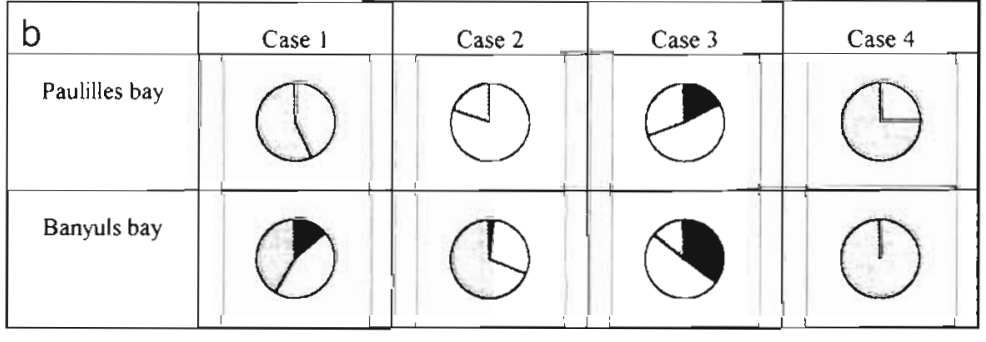

Early deposit

Successful recruitment

Outside of the recruitment zones

Fig. 10. (a) A schematic representation of the future of larvae spawned in the bays for the 4 wind conditions (cases 1 to 4 ) (symbols as in Fig. 8b) (b) Percent of larvae for each bay and for each configuration of wind according to their final status 


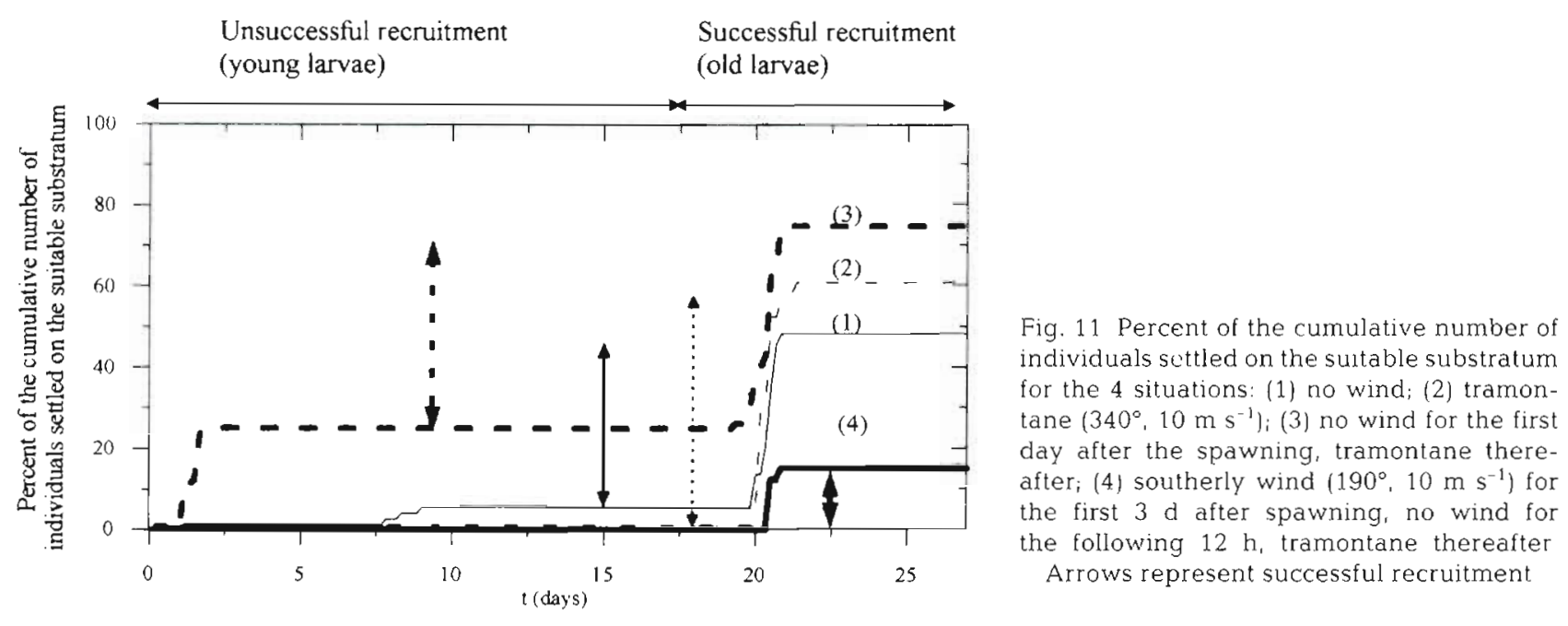

Fig. 11. For case 3, the first step corresponds to larvae which have settled too young on suitable substratum. The difference between the 2 steps represents successful recruitment $(50 \%)$ : larvae have reached the bottom between 19.3 and $20.8 \mathrm{~d}$ old; they are then at stage 4 of their development (Fig. 4),

Fig. 11 shows the effect of variability of the wind conditions on successful larval recruitment, which is higher $(60 \%)$ when the tramontane is blowing during all the pelagic phase (case 2). The poorest recruitment (15\%) occurs when the southerly wind is blowing first (case 4). Indeed, this wind generates upward currents (Fig. 6b), while the tramontane creates downward ones; all the larvae spawned in Banyuls Bay are first transported northwards by the horizontal surface currents (Fig. 6a) and when they reach a position offshore of Paulilles Bay, they are carried southeastwards and go out through the eastern open boundary of the considered zone. For case 1 , the successful recruitment is $43 \%$. It is lower than the 2 cases of tramontane (cases 2 and 3 ).

For the 4 situations, recruited larvae are between 19.3 and 21.8 d old. They are mostly transported near the coast where the current is low and depth shallow (about $12 \mathrm{~m}$ ). Larvae then settle on the substratum. under their own sinking velocity, which is $7.8 \mathrm{~m} \mathrm{~d}^{-1}$ for a 20 d old larvae (Fig. 4).

If we follow each larva under the 4 situations, we notice that larvae recruited in Paulilles Bay come from this zone and the same occurs for individuals recruited in Banyuls Bay. This may indicate that no mixing occurs between populations of the 2 zones. For case 3 , larva no. 17 (Fig. 8a) spawned in Paulilles Bay has reached the bottom at the south of the studied area but just outside Banyuls Bay, where there is a substratum suitable to the benthic development of Owenia fusiformis. This may indicate that for special tramontane conditions, some larvae originating from Paulilles Bay could settle in Banyuls Bay.

\section{Larval recruitment from other bays}

With the wind conditions of cases 3 or 4 , some larvae, between 0.7 and $1.3 \mathrm{~d}$ old, leave the studied zone through the eastern and southern open boundaries. If some larvae leave the studied zone, the same phenomenon can occur for larvae originating in an outside bay further to the north (Figs. 1b \& 3). We consider $28 \mathrm{~h}$ old larvae coming into the studied zone through the northern open boundary. For the different wind conditions (cases 1,2 and 4), no successful recruitment occurs. However, when the tramontane is blowing, $4.3 \%$ of larvae at stage 4 settle onto the bottom in the south of the studied zone but outside Banyuls Bay which is covered with a substratum suitable to the benthic development of Owenia fusiformis (Fig. 3); such larvae are also considered as dead individuals. For the other cases (1 and 4), larvae do not enter the bays and go out through the eastern and southern boundaries of the considered domain.

\section{DISCUSSION}

It has been shown in several bays that hydrodynamics should flush larvae offshore, but under some wind conditions, retention of larvae by wind-induced physical structure could be the main mechanism of recruitment (Johnson et al. 1986, McConaugha 1988, Epifanio et al. 1989). The latter studies only concerned crab larvae. Works on other benthic invertebrates with meroplanktonic larvae are scarce. We have focused our study on the dispersal of Owenia fusiformis larvae. An important role of our coupled physical-biological model is to weigh the importance of the different processes. In our model, we consider the physics accurately but simplify the biology in order to focus mainly on the effect of wind-driven 
larval transport. So, our results should be seen as a first step.

We have shown that the initial conditions of starting points of the larvae were very important for their trajectories, and we definitely believe that changes in several parts of the model (scheme resolution, forcing functions, biological processes) could dramatically change the results. We will discuss the present results of the model and define possible directions for future progress.

\section{Hydrodynamics simulated by the model}

Justification of a 3-D $k-\varepsilon$ model

The choice of a 3-D model is first justified by its good representation of wind-driven currents and of the influence of the bathymetry on the circulation (VerdierBonnet 1996). Secondly, it is necessary to account for the influences of vertical velocity shear on larvae and to consider the variations in buoyancy of the larvae. Many depth-averaged models (Hill 1990, 1991, Salomon 1990, Oliver et al. 1992, Richards et al. 1995) have been used to investigate pelagic larval dispersal when the vertical effects can be ignored: larvae are then assumed to be neutrally buoyant and uniformly distributed throughout a given section of the water column; the current is a depth-averaged velocity but in reality it may vary considerably in direction and speed from the surface to the seabed. Such models are well adapted for tidal currents in large domains such as the English Channel (Salomon 1990) or the Irish Sea (Hill 1990, 1991).

The influence of the turbulence closure model was not significant in the simulations presented in this paper. However, when the wind is blowing over a stratified fluid, the main advantage of the $k-\varepsilon$ turbulence closure model is the elimination of baroclinic instabilities in the upper part of the ocean by the local calculation of the vertical eddy viscosity (Verdier-Bonnet et al. 1997). Moreover, this model could represent small-scale interactions between prey and predators of larvae for the turbulence-dependent encounter rates between small organisms (Strickler 1985, Raby et al. 1994. Caparroy \& Carlotti 1996). The encounter rate is then expressed as a function of the dissipation rate $\varepsilon$ of the turbulent kinetic energy $k$ and of the Kolmogorov scale $\sigma, \sigma=\left(v^{3} / \varepsilon\right)^{0.25}$, with $v$ the molecular viscosity of the fluid. The $k-\varepsilon$ turbulence closure model calculates all the turbulence quantities needed for such biological models.

Few measurements of current have been made in Banyuls Bay (Rouault 1971, Nozais 1996). They have been used to determine the value of the current im- posed at the northern boundary, but they are so few that it is not possible to quantitatively compare our results to them. For southerly winds, in situ measurements indicate an upwelling zone near the coast (Nozais 1996) in agreement with our results (Fig. 6), Measurement series are planned.

\section{External forcings}

The chosen scenarios of winds are consistent with the wind measurements $\left(8 \mathrm{~d}^{-1}\right)$ at Cape Bear between March and April 1990 to 1993 (Table 1, Fig. 2). Situations near reality, considering the variations of wind every $3 \mathrm{~h}$, could be modelled. For this future objective, the characteristics of the OCKE3D model are well adapted. Nevertheless, this will require a great deal of computer memory to record enough velocity fields.

For upwelling or downwelling configurations, the variations in the vertical velocity, respectively upwards or downwards, are a key factor in the pelagic larval dispersion (Jacobsen et al. 1990, Dekshenieks et al. 1996): for upwelling conditions, larvae are found in the upper water column, and for downwelling, vertical downward velocities tend to concentrate larvae in the lower portion of the water column. Hence, the potential for dispersal may be greater under upwelling conditions, for southerly winds here (beginning of case 4), since larvae are more frequent in the water column. The kinetics of recruitment simulated by the model shows a correlation between the different wind conditions and the settlement of larvae (Figs. 10b \& 11). In some cases too-early recruitment was registered. Such a situation has been observed for Owenia fusiformis larvae in field studies (Dauvin 1992).

Many studies (Wroblewski 1980, Roughgarden et al. 1988, Jenkins \& Black 1994, Tremblay et al. 1994, Hinckley et al. 1996) consider wind as the main physical forcing. But for some sites, tides (Jenkins \& Black 1994, Tremblay et al. 1994, Richards et al. 1995), tidal bores (Pineda 1991, 1994), fronts (Dekshenieks et al. 1996) or internal waves (Shanks 1985, Shanks \& Wright 1987) have to be considered too because they may commonly transport larvae in coastal environments.

In Banyuls Bay, when the east wind is blowing offshore, a heavy swell enters the bay. The influence of the swell on larval dispersal may be worth studying in Banyuls Bay. To the authors' knowledge, no work concerning the modelling of the influence of the swell on larval dispersal has been done. The characteristic scales of swells are about $6 \mathrm{~s}$ in time and about $70 \mathrm{~m}$ in spatial length. Our model is not adapted at all for swell modelling: firstly the swell characteristic length is smaller than the horizontal mesh size used, and sec- 
ondly swell modelling involves a completely different physical approach with other assumptions such as a perfect fluid and no turbulence (Lajoie 1996).

Some works (Eckman et al. 1990) are restricted to the turbulent boundary layer 1 to $20 \mathrm{~m}$ above the sea bed. The settlement velocity of the larvae is then considered as a function of the bottom shear. In this paper, we assume a passive deposition of larvae with sinking velocities related to larval weight.

\section{Scheme resolution and size of the studied site}

The size of the mesh grid, with cells of $200 \mathrm{~m}$ in the 2 horizontal directions and $4 \mathrm{~m}$ for the vertical, could appear to be too coarse to adequately represent the currents near the coast in the adjacent $1 \mathrm{~km}$ strip and with depths less than $30 \mathrm{~m}$ (Fig. 3). However our aim was only to demonstrate the specifications of our method and not to be close to real situations. Now, we could consider refining the mesh vertically and horizontally in the 2 spawning zones in order to precisely model the phenomena near the coast with a better definition of the depth and of the coastal line. This would lead to an increase in calculation time. The calculated currents would then have to be compared with in situ measurements.

Under some wind conditions, some larvae go out of the bay. It might be worth taking a larger domain with several bays and with an open eastern offshore boundary far from the coast (Jenkins \& Black 1994), in order to model coastal processes which are characterised by a spatial scale of the order of some kilometres and mesoscale processes with a spatial scale of about $100 \mathrm{~km}$. This would need a very complicated physical model, using for example a conservative matching of non-uniforming grids with the nested multi-level zoom FIC method (Angot \& Laugier 1994). For this new problem, the temperature and food spatial variations would have to be taken account of, as done by Hinckley et al. (1996). A larger studied domain leads also to an approach very different from ours

\section{Biology}

Owenia fusiformis is a species with a $3 \mathrm{wk}$ pelagic phase and a reduced benthic distribution area (Snelgrove \& Butman 1994, Arnoux et al. 1995). However, the larvae settle on a large range of substrata, larger than the adult habitat. Although $O$. fusiformis is a relatively well studied species, its distribution is not well understood (Snelgrove \& Butman 1994). O. fusiformis larvae are still assumed to accumulate passively in areas with weak currents (Fager 1964, Butman 1987).
Particle tracking models

Many advection-diffusion-mortality models, solving a non-conservative equation for the concentration of individuals, have been developed to investigate pelagic larval dispersal (Wroblewski 1980, Hill 1990, 1991, Possingham \& Roughgarden 1990, Oliver et al. 1992, Richards et al. 1995, Carlotti 1996). For simple academic cases, an analytical solution has been found (Hill 1990, 1991, Richards et al. 1995). This Eulerian approach is well adapted for well-distributed concentrations of individuals without great spatial gradients because its accuracy is of the order of the mesh size. Our results show that 2 larvae issued from the same cell have very different trajectories and consequently different futures (see for example the tracks of larvae nos. 8 and 14 in Fig. 8a). The Lagrangian method, which considers each individual, is more accurate than an Eulerian one, and so was better adapted for our problem.

We established an empirical law of sinking depending on age based on laboratory measurements made with an actographic device (Duchêne \& Nozais 1994, Rey 1995). Those measurements show indeed a large range of swimming behaviours and speeds (Nozais 1996). Pelagic larvae are able to control their position in the water column (Arnoux et al. 1995). A better relationship would be to link the sinking speed to biological characteristics (length, weight) as done by Dekshenieks et al. (1996). Diurnal vertical migrations were another factor not taken into account in the present model. Further, salinity, temperature, and water density can actively or passively modify the vertical position of larvae (Banse 1986). The OCKE3D model can represent temperature and salinity effects.

\section{Interpretation of the results}

The results of the model give some indications on the location of the larvae in the bays as a function of the wind conditions. They can orient future field sampling in order to validate our results. But the validation is not so easy because in the model many assumptions are made: in situ, the spawning period is not instantaneous but lasts several days; the wind conditions are more variable than those retained in the model. Our model. simulations suggest that the populations in the bays are semi-closed populations with significant recruitment back to the parental area. This phenomenon is consistent with the published observations: McConaugha (1992) has shown that the retention of larvae in the vicinity of parental population assures sufficient recruits to maintain the population; Hill et al (1.996) have shown that gyres can be identified as 
retention structures at the scale of small basins and that such eddies can be crucial for recruitment. The same phenomenon has been observed in the Bay of Seine for Owenia fusiformis (Thiébaut et al. 1994).

The fate of the larvae tracked by the currents appears to be determined early in the pelagic phase: either they can stay in an area with low advection gyres and wait until they are heavy enough to sink, or they are quickly drifted outside of the bay. A shorter pelagic duration would not change the fate of the 'lucky' larvae; on the contrary, it could reduce the chance of emigrated larvae finding another suitable area in another bay. Based on the maximal advective surface speed at the eastern border of the modelled area (Fig. 5a), larvae could be drifted $30 \mathrm{~km} \mathrm{~d}^{-1}$. A long larval duration then increases the tiny chance of being trapped in another bay gyre. In this case, the vertical swimming speed of the larvae is important, and should be investigated in realistic conditions (turbulence, horizontal flow) as done by Thiébaut et al. (1992) in the Bay of Seine. This role of extended development time in plankton has already been mentioned by ecologists (Jackson \& Strathmann 1981).

It is worth noting that the successful recruited larvae of the 2 bays (Banyuls and Paulilles) originate from the end of the bays where the highest densities of adults are observed (see Fig. 3b). The estimated recruitment of larvae could be obtained by multiplying the number of successfully recruited larvae by the density of the adults in the spawning zone (Fig. 3b), as done by Tremblay et al. (1994), and by the number of eggs spawned by each female. The averaged fecundities of 2,3 and 4 yr old Owenia fusiformis females are respectively estimated at 23400,39400 and 81100 ovocytes

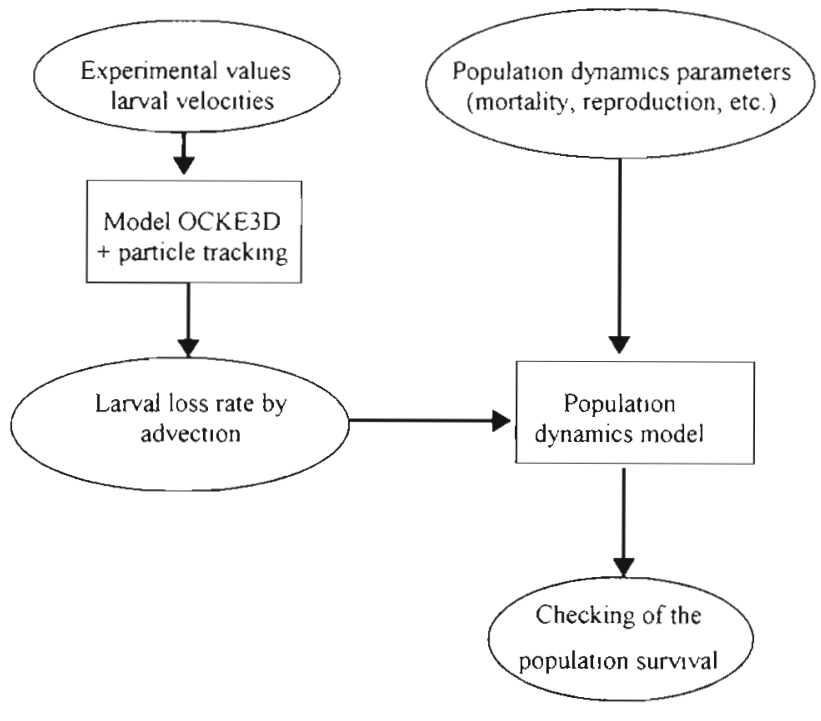

Fig. 12. Conceptual schema of the physico-biological model (Rey 1995) (see text for explanation)
(Thiébaut \& Dauvin 1991). Nevertheless, we do not yet have enough in situ data.

\section{CONCLUSION}

The understanding of settlement regulation needs to integrate processes across different spatial scales (Arnoux et al. 1995, Bertness et al. 1996). Coupled models of hydrodynamics and tracking particles are up to now the only way to follow 'animal navigation'. Knowledge of the trajectories of the individuals as well as their bioenergetics within the pelagic phase will enable us to shed light on variable recruitment.

The interest of the IBM (individual-based models) coupled with a physical model consists not only in increasing our understanding of the link between spatial and temporal dynamics of meroplanktonic populations but also in allowing us to explore the potential effects of habitat alteration on those populations. From a numerical approach, using a physical 3-D model, the current regime in a coastal zone has been described, allowing simulation of the trajectory of larval particles. The result is a quantification of the influence of the wind on larval recruitment. The model incorporated successively several constraints which could vary in time. Simulations allowed the deduction of the advection losses. The proportion of larvae reaching the adult habitat was $60 \%$ at maximum. Although this is evidence of the importance of physical advection in the recruitment process, it must be considered only as an indication and compared with estimated losses based on population dynamics (Fig. 12) and in situ measurements. A possible test of our hypathesis that larvae retained above the adult area are crucial for the recruitment would be to conduct field sampling on a very fine scale above this area, with observations of surrounding gyres.

Acknowledgements. This work was carried out as a part of the 'Programme National sur le Déterminisme du Recrutement' (PNDR GLOBEC, France, IFREMER/CNRS).

\section{LITERATURE CITED}

Angot P, Langier M (1994) La méthode FIC de raccordement conservatif de sous-domaines emboîtes pour un modèle de circulation océanique. C R Acad Sci Paris, Sér II, 319: 993-1000

Arnoux S, Bhaud M, Cazaux C, Cha JH, Duchêne JC, Fraunié P, Marcano G, Martin D, Nattero MJ. Nozais C, Pinedo S, Rey C, Sarda R (1995) Recruitment in the light of biological-physical interactions in coastal waters: results of PNDR action at the Arago Laboratory in 1994-1995. Vie Milieu 45(2):85-105

Banse K (1986) Vertical distribution and horizontal transport of pelagic larvae of echnoderms and benthic polychaetes in an open coastal sea. Bull Mar Sci 39:162-175 
Bertness MD, Gaines SD, Wahle RA (1996) Wind-driven settlement patterns in the acorn barnacle Semibalanus batanoides Mar Ecol Prog Ser 137:103-110

Bhaud M, Cazaux C, Watson Russell C, Lefèvre M (1987) Description and identification of Polychaete larvae; their implications in current biological problems. Océanis 13(6): $596-753$

Black KP, Moran PJ (1991) Influence of hydrodynamics on the passive dispersal and initial recruitment of larvae of Acanthaster planci (Echinodermata: Asteroidea) on the Great Barrier Reef. Mar Ecol Prog Ser 69:55-65

Black KP, Moran PJ, Hammond LS (1991) Numerical models show coral reefs can be self seeding. Mar Ecol Prog Ser 74 $1-11$

Butman CA (1987) Larval settlement of soft-sediment invertebrates: the spatial scales of pattern explained by active habitat selection and the emerging role of hydrodynamic processes. Oceanogr Mar Biol Annu Rev 25:113-165

Caparroy Ph, Carlotti F (1996) A model of the ingestion of Acartia tonsa: effect of turbulence and consequences for the related physiological processes. J Plankton Res 18(11): $2139-2177$

Carlotti F (1996) Simulations of the population dynamics of Pectinaria koreni in a $2-D$ vertical advection-diffusion model of the Seine estuary. Oceanol Acta 19(3-4):369-383

Chia FS, Buckland-Nicks J, Young CM (1984) Locomotion of marine invertebrate larvae: a review. Can J Zool 62: $1205-1222$

Dauvin JC (1992) Cinétique du recrutement et croissance des juvéniles d'Owenia fusiformis Delle Chiaje en Baie de Seine (Manche orientale). Oceanol Acta 15:187-196

Dekshenieks MM, Hofmann EE, Klinck JM, Powell EN (1996) Modeling the vertical distribution of oyster larvae in response to environmental conditions. Mar Ecol Prog Ser 136:97-110

De Wolf $\mathrm{P}$ (1974) On the retention of marine larvae in estuaries. Thal Jugosl 10:415-424

Duchêne JC, Nozais C (1994) Light influence on larval emission and vertical swimming in the terebellid worm Eupolymnia nebulosa (Montegu, 1818). Mém Mus nat Hist Nat 162:405-412

Eckman JE (1994) Modelling physical-biological coupling in the ocean: the US GLOBEC Program. Deep Sea Res II $41(1): 1-5$

Eckman JE, Werner FE, Gross TF (1990) Modelling some effects of behavior on larval settlement in a turbulent boundary layer. Deep Sea Res II 41(1):185-208

Epifanio CE Masse AK, Garvine RW (1989) Transport of blue crab larvae by surface currents off Delaware Bay, USA. Mar Ecol Prog Ser 54:35-41

Fager EW (1964) Marine sediments: effects of a tube-building polychaete. Science 143:356-359

Guille A (1971) Bionomie benthique du plateau continental de la côte catalane française IV. Densités, biomasses et variations saisonnières de la macrofaune. Vie Milieu 22 (1B):94-111

Hill AE (1990) Pelagic dispersal of Norway lobster Nephrops norvegicus larvae examıned using an advection-diffusionmortality model. Mar Ecol Prog Ser 64:217-226

Hill AE (1991) Advection-diffusion-mortality solutions for investigating pelagic larval dispersion. Mar Ecol Prog Ser $70: 117-128$

Hill AE, Brown J, Fernand L (1996) The western Irish Sea gyre: a retention system for Norway lobster (Nephrops norvegicus). Oceanol Acta 19(3-4):385-396

Hinckley S, Hermann AJ, Megrey BA (1996) Development of spatially explicit, individual-based model of marine fish early life history. Mar Ecol Prog Ser 139:47-68

Jackson GA, Strathmann RR (1981) Larval mortality from offshore mixing as a link between precompetent and competent periods of development. Am Nat 118:16-26

Jacobsen TR, Milutinovic JD, Miller JR (1990) Observational and model studies of physical processes affecting benthic larval recruitment in Delaware Bay. J Geophys Res 95: 20331-20345

Jenkins GJ, Black KP (1994) Temporal variability in settlement of a coastal fish (Sillaginades punctata) determined by low-frequency hydrodynamics. Limnol Oceanogr 39(7): $1744-1754$

Johnson DF, Botsford LW, Methot RD, Wainwright TC (1986) Wind stress and cycles in Dungeness crab Cancer magister, catch of California, Oregon and Washington. Can J Fish Aquat Sci 43:838-845

Lagadeuc Y (1990) Processus hydrodynamiques, dispersion larvaire et recrutement en régime mégatidal. Exemple de Pectinaria koreni (Annélide polychète) en baie de Seine (Manche). Thèse de doctorat, Université des Sciences et Techniques de Lille Flandres-Artois

Lajoie D (1996) Modélisation de la houle en zone côtière: mise au point d'atténuateurs de houle dynamiques. Thèse de doctorat, Université de la Méditerranée, Aix-Marseille II

Lambert R (1991) Recrutement d'espèces benthiques à larves pélagiques en régime mégatidal. Cas de Pectinaria koreni (Malmgren), Annélide polychète. Thèse de Doctorat, Université de Rennes I

McConaugha JR (1988) Export and reinvasion of larvae as regulators of estuarine decapod populations. Am Fish Soc Symp 3:90-103

McConaugha JR (1992) Decapod larvae: dispersal mortality, and ecology. A working hypothesis. Am Zool 32:512-523

Mileikovsky SA (1973) Speed of active movement of pelagic larvae of marine bottom invertebrates and their ability to regulate their vertical position. Mar Biol 23:11-17

Nozais C (1996) Impact des processus biologiques et des paramètres physiques sur la présence planctonique des larves d'invertébrés benthiques et sur leur recrutement en baie de Banyuls. Thèse de doctorat, Université de Paris VI

Oliver JK, King BA, Willis BL, Babcock RC, Wolanski E (1992) Dispersal of coral larvae from a lagoonal reef - II. Comparisons between model predictions and observed concentrations. Cont Shelf Res 12(7/8):873-889

Peyret R, Taylor TD (1983) Computational methods for fluid flow. Springer-Verlag, New York, p 27-29

Pineda J (1991) Predictable upwelling and shoreward transport of planktonic larvae by internal tidal bores. Science 253:548-551

Pineda J (1994) Internal tidal bores in the nearshore: warm water fronts, seaward gravity currents and the onshore transport of larvae. J Mar Res 52:427-458

Planes S (1993) Genetic differentuation in relation to restricted larval dispersal of the convict surgeonfish Acanthurus triotegus in French Polynesia. Mar Ecol Prog Ser 64:55-68

Possingham HP, Roughgarden J (1990) Spatial population dynamics of a marine organism with a complex life cycle. Ecology 71(3):973-985

Raby D, Lagadeuc Y, Dodson JJ, Mingelbier M (1994) Relationship between feeding and vertical distribution of bivalve larvae in stratified and mixed waters. Mar Ecol Prog Ser 103:275-284

Rey C (1995) Originalité du recrutement benthique chez Owenia fusiformis, Polychaeta: disséminatıon larvaire et rapport avec le substrat. Rapport de stage de DEA, Unıversité de Paris VI (Laboratoire Arago) 
Richards SA, Possingham HP, Noye BJ (1995) Larval dispersion along a straight coast with tidal currents: complex distribution patterns from a simple model. Mar Ecol Prog Ser 122:59-71

Rouault C (1971) Etude dynamique des eaux du plateau continental dans la région de Banyuls-sur-mer. Thèse de 3ème cycle, Université de Paris VI

Roughgarden J, Gaines SD, Possingham HP (1988) Recruitment dynamics in complex life cycles. Science 241. $1460-1466$

Salomon JC (1990) Role of instantaneous and longterm water movements on the recruitment and life of benthic fauna in the English Channel. La Mer 28(4):211-217

Scheltema RS (1986) On dispersal and planktonic larvae of benthic invertebrates: an eclectic overview and summary of problems. Bull Mar Sci 39(2):290-322

Shanks A.L (1985) Behavioural basis of internal-wave induced shoreward transport of megalopae of the crab Pachygrapsus crassipes. Mar Ecol Prog Ser 24:289-295

Shanks A. Wright WG (1987) Internal-wave mediated shoreward transport of cyprids, megalopae, and gammarids and correlated longshore differences in the settling rate of intertidal barnacles. J Exp Mar Biol Ecol 114:1-13

Snelgrove PVR, Butman CA (1994) Animal-sediment relationships revisited: cause versus effect. Oceanogr Mar Biol Annu Rev 32:111-177

Strickler JR (1985) Feeding currents in calanoid copepods two new hypotheses. In: Laveraks MS (ed) Physiological adaptations of marine animals. Symp Soc Exp Biol 89: $459-485$

Thiébaut E, Dauvin JC (1991) Etude de la fécondıté d'Owenia fusiformis Delle Chiaje (Annélide Polychète). J Rech Océanogr 16(1,2):39-41

Editorial responsibulity: Otto Kinne (Editor),

Oldendorf/Luhe, Germany
Thiébaut E, Dauvin JC, Lagadeuc Y (1992) Transport of Owenia fusiformis larvae (Annelida: Polychaeta) in the Bay of Seine. I. Vertical distribution in relation to water column stratification and ontogenic migration. Mar Ecol Prog Ser $80: 29-39$

Thiébaut E, Dauvin JC, Lagadeuc Y (1994) Horizontal distribution and retention of Owenia fusiformis larvae (Annelida: Polychaeta) in the Bay of Seine. J Mar Biol Assoc UK 74: $129-142$

Thiébaut E (1994) Dynamique du recrutement et dispersion larvaire de deux annélides polychètes Owenia fusiformis et Pectinaria koreni en régime mégatidal (Baie de Seine orientale, Manche). Thèse de doctorat, Université de Paris VI

Tremblay MJ, Loder JW, Werner FE, Naimie CE, Page FH, Sinclair MM (1994) Drift of sea scallop larvae Placopecten magellanicus on Georges Bank: a model study of the roles of the mean advection, larval behavior and larval origin. Deep Sea Res II 41 (1):7-50

Verdier-Bonnet C, Angot Ph, Fraunié Ph (1997) Paramétrisation de la turbulence pour le phénomène d'upwelling côtier en milieu stratifié. C R Acad Sci Paris, Sér Ilb 324: 229-238

Verdier-Bonnet C (1996) Modélisation des écoulements côtiers à surface libre et paramétrisation de la turbulence. Application à la dissémination larvaire. Thèse de doctorat, Université de la Méditerranée, Aix-Marseille II

Wilson DP (1932) On the Mitrana larvae of Owenia fusiformis Delle Chiaje. Phil Trans R Soc Lond Ser B Biol Sci 221: 231-334

Wroblewski JS (1980) A simulation of the distribution of Acartia clausi during the Oregon Upwelling. J Plankton Res 2: $43-68$

Submitted: June 26, 1997; Accepted: September 29, 1997

Proofs received from author(s): December 8, 1997 